\title{
A southeastern Mediterranean PV streamer and its role in December 2001 case with torrential rains in Israel
}

\author{
S. O. Krichak, P. Alpert, and M. Dayan \\ Department of Geophysics and Planetary Sciences, Raymond and Beverly Sackler Faculty of Exact Sciences, Tel Aviv \\ University, Ramat Aviv, Tel Aviv, 69978, Israel
}

Received: 8 November 2006 - Revised: 15 December 2006 - Accepted: 15 December 2006 - Published: 10 January 2007

\begin{abstract}
A precipitation event of unprecedented intensity took place over northern part of Israel during 4 December 2001-5 December 2001. The case was associated with formation of a Cyprus Low cyclone over the Asia Minor. In the current study the synoptic developments over the eastern part of the Mediterranean region are simulated with the MM5 nonhydrostatic model and analyzed based on dynamic tropopause patterns calculated from the simulation results. According to the results, a powerful potential vorticity (PV) streamer system played a major role in the process over the southeastern Mediterranean region. The PV streamer created conditions for seclusion of moist air masses from the equatorial East Africa and Atlantics during the cyclone development. Condensation of the moisture, associated with the latent heat release processes have contributed to the intense thunderstorm activity and heavy precipitation of the event.
\end{abstract}

\section{Introduction}

Torrential rains fell over Israel during the period from 00:00 UTC, 4 December 2001 to 00:00 UTC 5 December 2001. The rains (up to $250 \mathrm{~mm}$, about $200 \mathrm{~mm}$ during the 01:00 UTC-07:00 UTC time interval of 4 December 2001) were observed over a narrow coastal zone in the northern part of the country $\left(\sim 32.5^{\circ} \mathrm{N} ; 34.7^{\circ} \mathrm{E}\right)$. No comparable rainfall intensity has ever been recorded over the area which is characterized by mean annual precipitation of about $650 \mathrm{~mm}$. Rains also fell over the other parts of the country, though their intensity was decreasing southwards. The rains were associated (Krichak et al., 2004, hereafter KAD) with a "Cyprus Low" (CL) cyclone (El-Fandy, 1946; Kallos and Metaxas, 1980,) which acted over the eastern Mediterranean area during 2 December 2001-5 December 2001.
The data available demonstrate a powerful synoptic process characterized by merging of the polar and subtropical upper-tropospheric jet streams over the Mediterranean region. The process was associated with the formation of a mesoscale convective complex (MCC; Caracena et al., 2001; Cotton, 1990; Maddox, 1980) and its further transformation into a cyclone under the left-front part of the jet stream system. Location of the area with the cyclone development allows attributing the process to the effects of a quiasi-geostrophic imbalance between the pressure gradient and Coriolis forces (Bjerknes, 1951; Keyser and Shapiro, 1986; Uccellini, 1980; Uccellini and Kocin, 1987; Pyle et al., 2004). The explanation is insufficient however for understanding the unprecedented intensity of the precipitation event.

In this paper the evolution of synoptic processes during 3 December 2001-5 December 2001 is analyzed based on the data from the NCAR/NCEP reanalysis archive as well as Meteosat water vapor imageries. Additionally, a hydrodynamic model simulation of the synoptic event is performed. The model produced data are adopted for a higher resolution evaluation of the period. The analysis is complemented by an evaluation of dynamic tropopause maps calculated from the results of the model simulation.

Section 2 presents results of a synoptic analysis of the period with the extreme precipitation event in Israel on 45 December 2001. The methodology adopted for a highresolution simulation of the synoptic developments with mesoscale atmospheric model MM5 as well as an evaluation of the simulation results are presented in Sect. 3. Section 4 describes the principles of the dynamic tropopause evaluations. An evaluation of dynamic tropopause maps representing the synoptic processes of the period is discussed in Sect. 5. Section 6 summarizes results obtained in the study.

Correspondence to: S. O. Krichak

(shimon@cyclone.tau.ac.il)

Published by Copernicus GmbH on behalf of the European Geosciences Union. 


\section{Major large-scale synoptic developments}

The data from the National Center for Environmental Prediction/National Center for Atmospheric Research Reanalysis Project (NNRP) archive (Kalnay et al., 1996; Kistler et al., 2001) are adopted for synoptic evaluation of the processes that took place during 3 December 2001-5 December 2001 over the eastern part of the Mediterranean region. The NNRP data are derived through a consistent assimilation and forecast model procedure, which allows the incorporation of all available observation data. The NNRP data assimilation system includes the T62/28-level global spectral model with horizontal resolution of about $210 \mathrm{~km}$. The reanalysis data are available with $2.5^{\circ}$ lat $\times 2.5^{\circ}$ lon horizontal spacing. KAD has demonstrated the reliability of the NNRP data for understanding the relevant weather processes happening between the end of November and the beginning of December 2001.

\subsection{Lower-troposphere processes}

The NNRP-based sea level pressure (SLP) and $700 \mathrm{hPa}$ specific humidity (SHUM) patterns over Europe and the Mediterranean region at 00:00 UTC, from 2 December 2001 to 5 December 2001 are presented in Figs. 1a-d, respectively.

In Fig. 1a at 00:00 UTC 2 December 2001 an intense moist advection from the Scandinavian and Alpine regions in the direction of the Mediterranean region may be noted. Another moist-air zone over the Arabian Peninsula links the Mediterranean area with the equatorial east-Africa. Formation of a Red Sea Trough (RST) (Krichak et al., 1997a, b; Krichak and Alpert, 1998; Ziv et al., 2004) may be also noted. Large amounts of moist air are found around in the Mediterranean cyclone, which is located over Crete (minimum pressure of $1005 \mathrm{hPa}$ ). High SLP values and an unusually western position of the Siberian anticyclone which is connected to the Azorean High may be also noted. The high-pressure belt separates the two areas (over the northern Atlantic and eastern Mediterranean regions) with active cyclone developments.

At 00:00 UTC 3 December 2001 (Fig. 1b) a Mediterranean cyclone belonging to a well developed RST system is found near Cyprus. The moist-air transport to the area over Europe and the Arabian Peninsula is in progress. The role of the southern branch of the moist air transport appears to be playing the main role in the process. Significant amounts of moist air from equatorial Africa are found here directed to the cyclone over Arabian Peninsula and the Middle East. Orientation of the moist-air zone as well as NNRP precipitation maps (not presented), allow assuming an important role of the latent heat release effects (Reed et al., 1992; Whitaker et al., 1988) in the Mediterranean cyclogenetic process. An eastward displacement of the Siberian anticyclone as well as deepening of the cyclone pressure $(985 \mathrm{hPa})$ in the northwestern part of the pattern indicate an increased interaction between the processes in the Mediterranean area with those over the northern Atlantics.

According to Fig. 1c the earlier noted tendency has strengthened during the following $24 \mathrm{~h}$. A decay and eastward displacement of the Siberian High $(1045 \mathrm{hPa})$ may be noted. The eastern Mediterranean cyclone $(1005 \mathrm{hPa})$ is approaching Cyprus. A large zone with the moist air from the equatorial Africa is also approaching the cyclone from the southeast. A well developed large scale trough is linking the area over the Arabian Peninsula with that to the west of the British Islands where a deep cyclone $(975 \mathrm{hPa})$ is found. The conditions are favorable for precipitation in Israel.

At 00:00 UTC 5 December 2001 (Fig. 1d) the zone with high concentration of the moist air of African origin is found separated from the CL system (central pressure of $1010 \mathrm{hPa}$ ). Significant amounts of moist air are already concentrated in the area.

\subsection{Upper-troposphere developments}

The wind magnitude fields in the upper-troposphere $(300 \mathrm{hPa})$ over the eastern part of the northern Atlantic, western European and North Africa regions during the 2 December 2001-5 December 2001 are presented in Figs. 2a-e at 00:00 UTC of each of the days, respectively.

The upper-troposphere winds at 00:00 UTC 2 December 2001 (Fig. 2a) demonstrate collision of the Polar and Subtropical jet streams (PJS and STJ) over the central Mediterranean - North Africa region. A narrow PJS zone with isolated wind maximum $\left(40 \mathrm{~m} \mathrm{~s}^{-1}\right)$ over the central Mediterranean region links the area with that over Scandinavian Peninsula. The discussed above (Fig. 1a) eastern Mediterranean cyclogenetic development takes place under the leftfront quadrangle of the PJS wind maximum.

The area with the wind maximum at the $\mathrm{STJ}\left(50 \mathrm{~m} \mathrm{~s}^{-1}\right)$ is located over the northern part of the Persian Gulf area. At 00:00 UTC 3 December 2001 (Fig. 2b) a significant intensification of the STJ (more than $50 \mathrm{~m} \mathrm{~s}^{-1}$ ) may be noted over the North Africa coastal area of the eastern Mediterranean region. The intensification appears to be a consequence of merging of the PJS wind maximum with the STJ. According to the earlier evaluations (Krichak et al., 1997a, b) such situations are favorable for the RST formation processes.

At 00:00 UTC 4 December 2001 (Fig. 2c) the zone with the STJ maximum $\left(50 \mathrm{~m} \mathrm{~s}^{-1}\right)$ over the south-eastern Mediterranean is situated westward of the Red Sea area. The zone with the STJ is linked with another high wind magnitudes zone (up to $70 \mathrm{~m} \mathrm{~s}^{-1}$ ) over the eastern Atlantics.

At 00:00 UTC 5 December 2001 (Fig. 2d) the STJ maximum $\left(50 \mathrm{~m} \mathrm{~s}^{-1}\right)$ is located over the Arabian Peninsula. An eastward shift of the high wind-speed maxima from the Atlantics to Alpine region illustrates the earlier noted role of the upper-tropospheric processes over the Atlantics in the Mediterranean area. 
(a) SLP (solid) SHUM-700 (shaded) NNRP 00021201

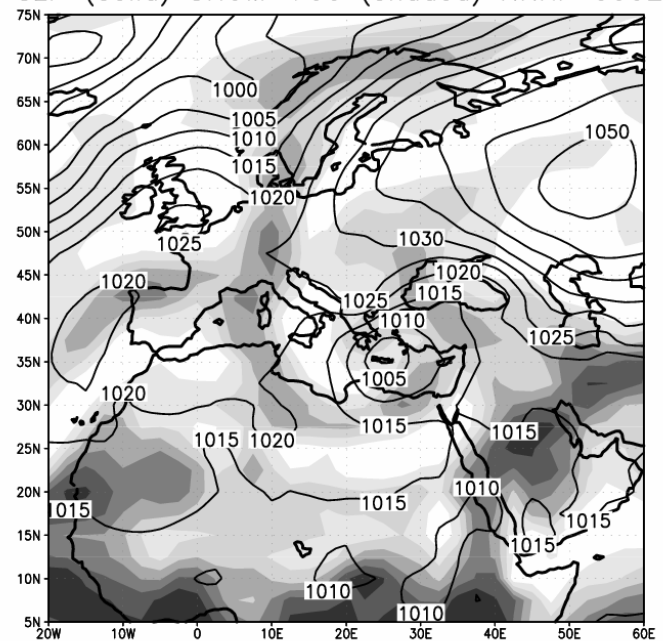

(c) SLP (solid) SHUM-700 (shaded) NNRP 00041201

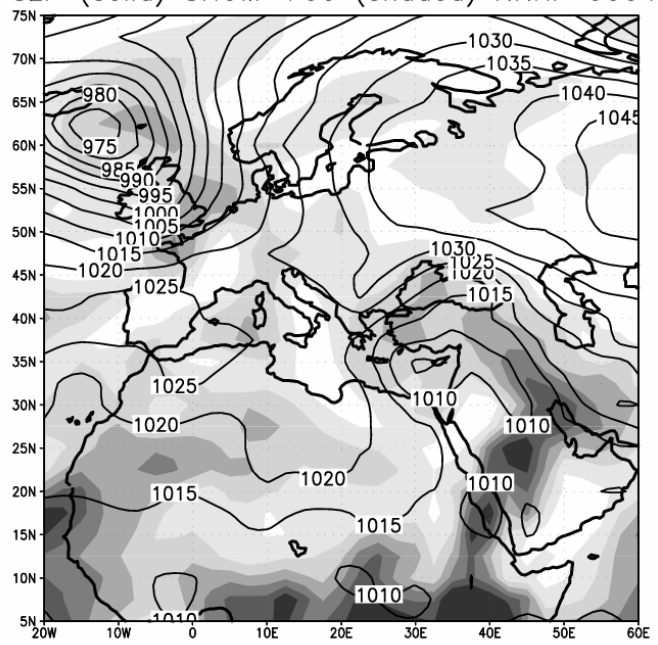

(b) SLP (solid) SHUM-700 (shaded) NNRP 00031201

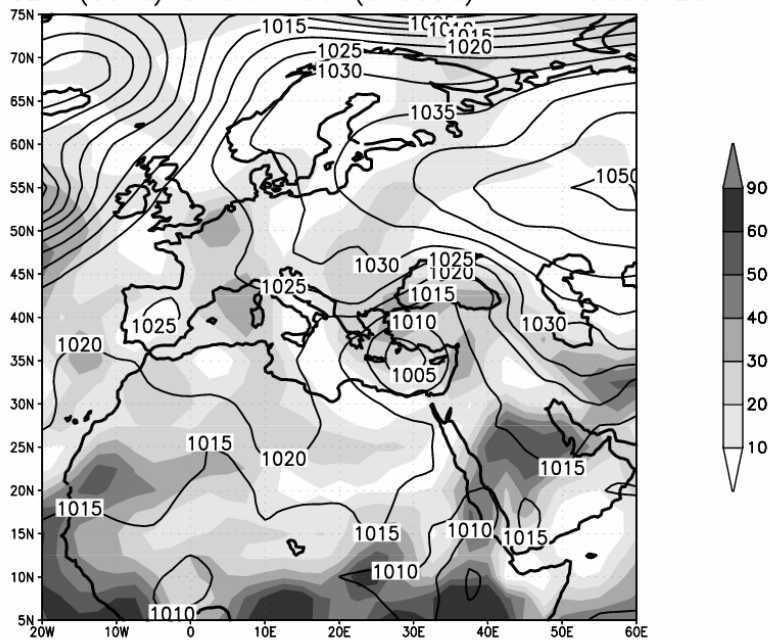

(d) SLP (solid) SHUM-700 (shaded) NNRP 00051201

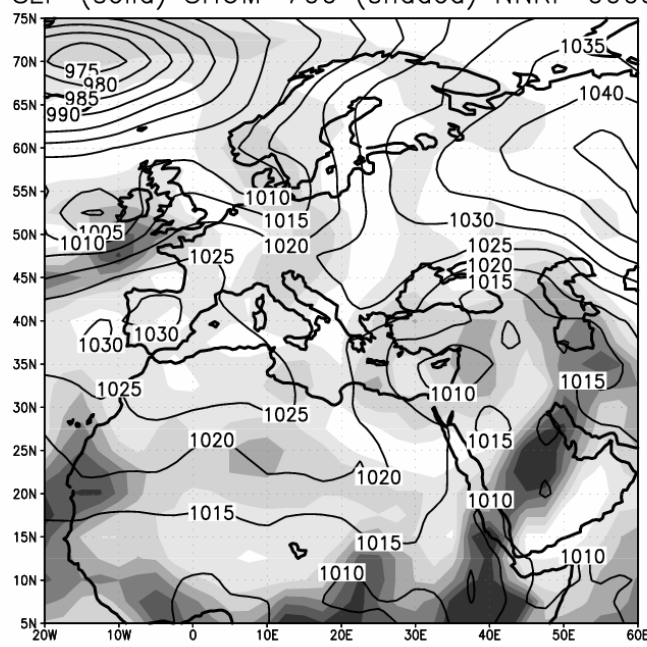

Fig. 1. Sea Level Pressure (hPa, solid lines), and $700 \mathrm{hPa}$ specific humidity $\left(\mathrm{g} \mathrm{kg}^{-1}\right.$, shading) over Europe at 00:00 UTC (a) 2 December 2001, (b) 3 December 2001, (c) 4 December 2001, (d) 5 December 2001.

\subsection{Representation of the process in WV imageries}

An important additional information on the eastern Mediterranean upper-troposphere developments of the period is available from the Meteosat Water Vapor (WV) imageries (C) Eumetsat 2003) given in Figs. 3a-d at (a) 12:00 UTC 3 December 2001; (b) 00:00 UTC 4 December 2001 (c) 12:00 UTC 4 December 2001; (d) 00:00 UTC 5 December 2001. The imageries are based on a band of emission by water vapor - hence regions of high upper-tropospheric humidity appear in the imageries as white zones whereas dark zones represent those with low humidity.

An extended dry zone situated along the southern coastal area of the eastern part of the Mediterranean region may be noted to the east of Greece (hereafter EM) in the in Fig. 3a at 12:00 UTC 3 December 2001. Another northward oriented dry-air zone is also found over the area. A moist air mass zone is situated over the area extending from Cyprus to the Black Sea. On the following picture at 00:00 UTC 4 December 2001 (Fig. 3b) the moist air zone over Cyprus is already almost separated from another moist zone to the southeast of the Black Sea. In 12 h, at 12:00 UTC 4 December 2001 (Fig. 3c) the zone with the moist air is already situated along the EM coastal zone. Almost no signs of the dry zone are found over the region in Fig. 3d at 00:00 UTC 5 December 2001.

The exceptional moist air mass seclusion which can be seen in Figs. 1b, d and 3a-d appears to be one of the main factors that led to the high concentration of moist air which made possible the unprecedented torrential rains in Israel on 4 December 2001-5 December 2001. In the following sections we investigate the mechanisms which contributed to the synoptic process. 
(a) Wind magnitude $300 \mathrm{hPa}$ NNRP 00021201

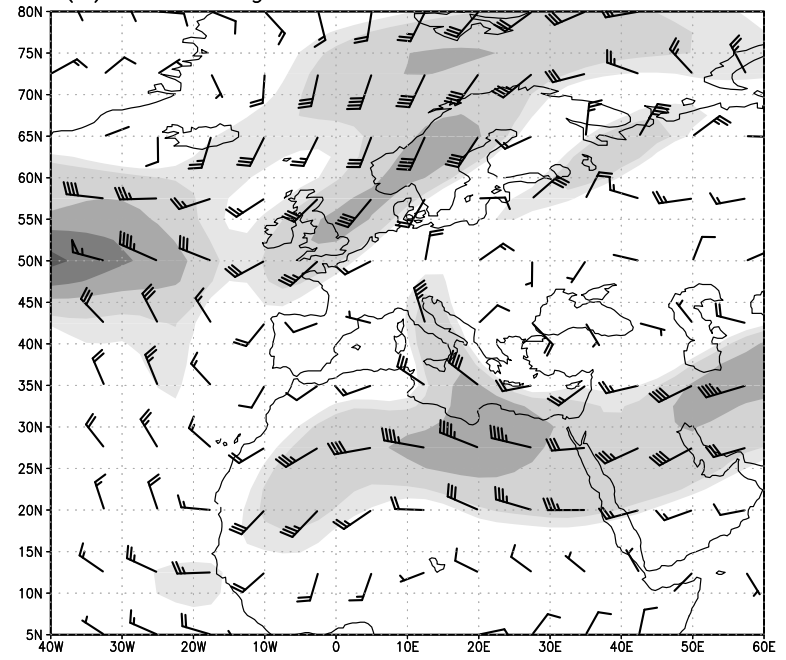

(c) Wind magnitude $300 \mathrm{hPa}$ NNRP 00041201

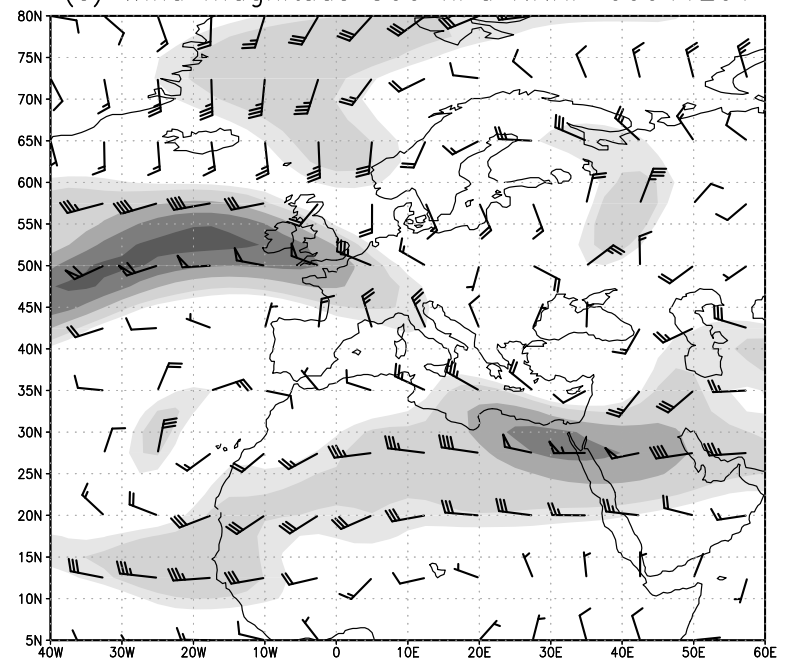

(b) Wind magnitude $300 \mathrm{hPa}$ NNRP 00031201

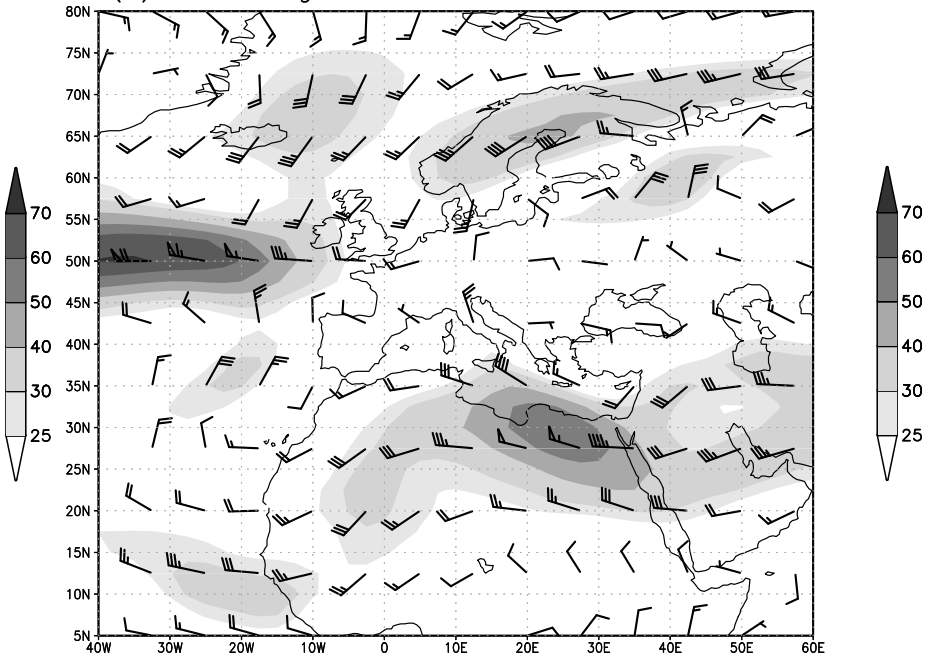

(d) Wind magnitude $300 \mathrm{hPa}$ NNRP 00051201

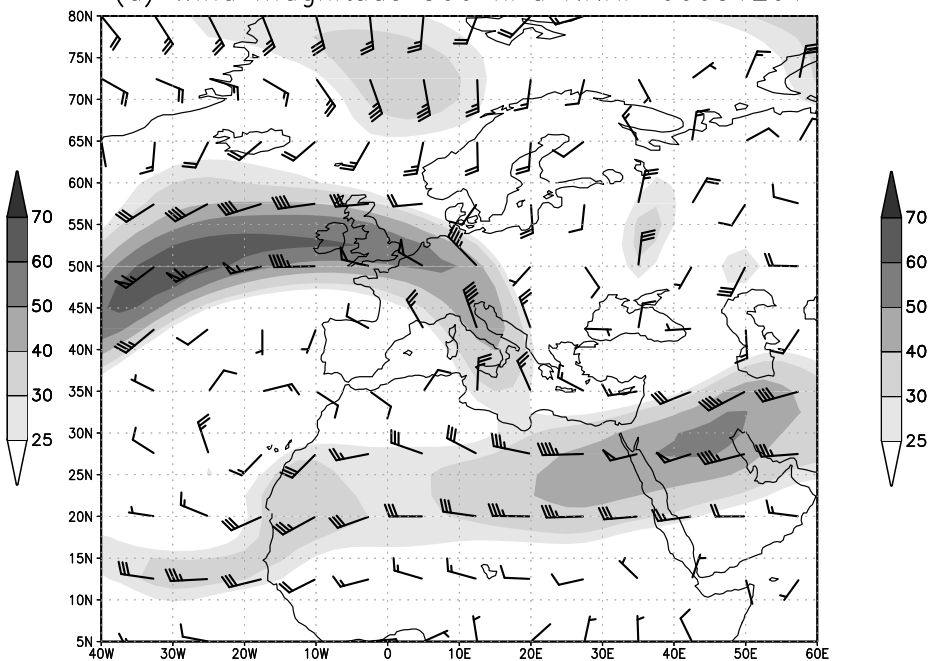

Fig. 2. Wind magnitude (contour interval $10 \mathrm{~m} \mathrm{~s}^{-1}$ ) at the $300 \mathrm{hPa}$ isobaric surface over Europe at 00:00 UTC (a) 2 December 2001, (b) 3 December 2001, (c) 4 December 2001, (d) 5 December 2001.

\section{Simulation with MM5}

As was demonstrated before the rainy event of 4 December 2001-5 December 2001 took place as a result of condensation of high amount of the air moisture during the intense mesoscale development over the northern Mediterranean region. The process was clearly forced by the effects of the upper-troposphere jet streams.

It has been demonstrated (Krichak et al., 2007) that the developments have been associated with a strong synoptic process in the upper-troposphere over the northern Atlantics associated with development of a coherent tropopause disturbance. A numerical simulation of the synoptic event has been performed to investigate the role of the process over the Mediterranean region. The experiment's plan was based on the assumption that a successful simulation of the Israeli pre- cipitation event requires an accurate representation of the observed upper-troposphere developments. In accordance with the suggestion the main focus in the following evaluation of the simulation results is made on the understanding them in comparison with the Meteosat WV imageries.

\subsection{Hydrodynamic model}

The Fifth Generation Penn State University/NCAR Mesoscale Model (MM5v3.6) (Dudhia et al., 2005; Grell et al., 1994) is adopted for the high-resolution simulation. The non-hydrostatic system of hydrodynamic equations including the fully compressible mass continuity equation is adopted in model (Dudhia at al., 2005). The equations are numerically approximated according to the Arakawa-B staggering grid stencil (Mesinger and Arakawa, 

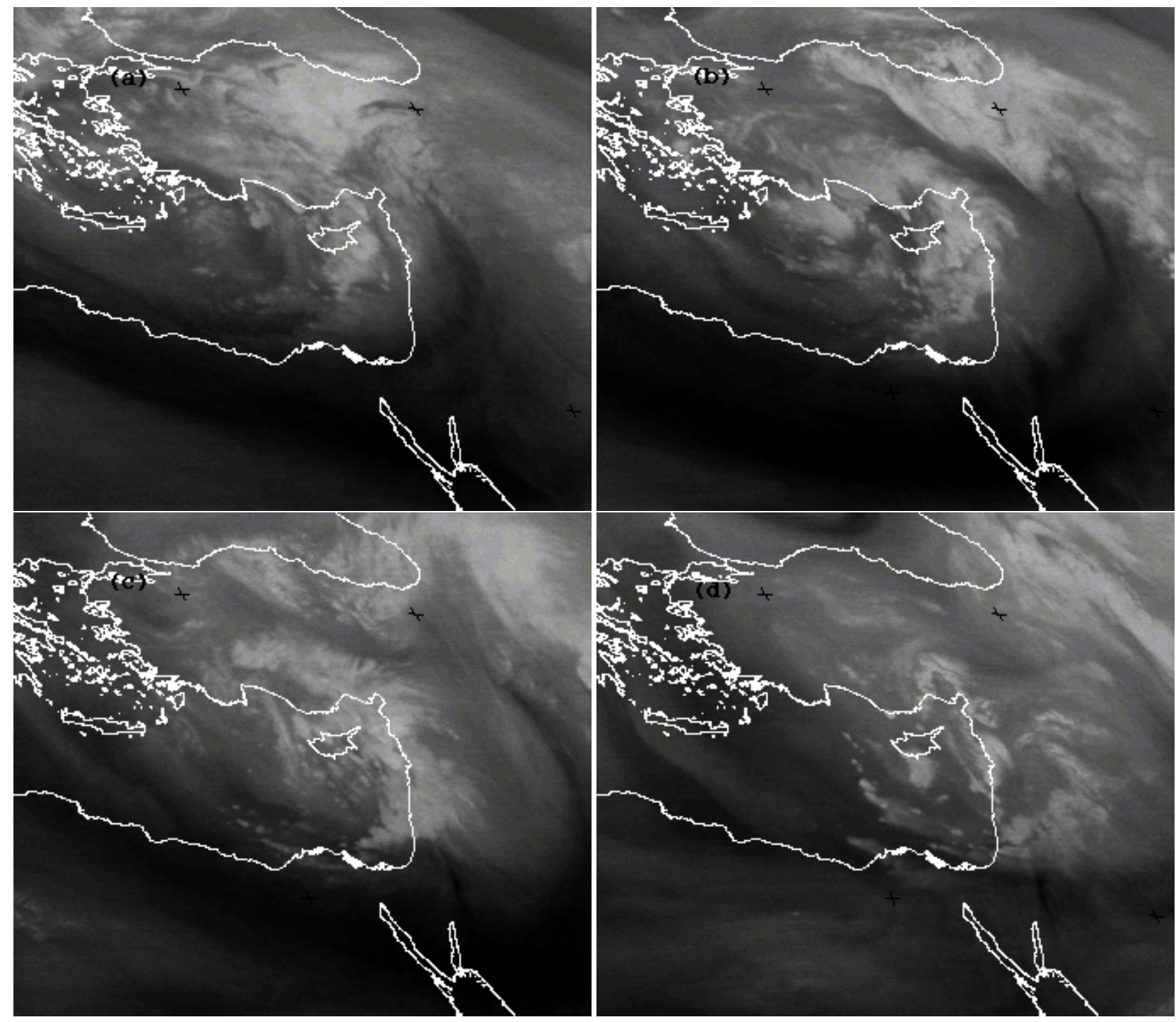

Fig. 3. Meteosat-7 ( Eumetsat 2003) water vapor imageries at (a) 12:00 UTC 3 December 2001, (b) 00:00 UTC 4 December 2001, (c) 12:00 UTC 4 December 2001, (d) 00:00 UTC 5 December 2001.

1976). The sigma terrain-following coordinate is used to represent the vertical structure of the atmosphere for the model characteristics. The model allows one- and two-way interactive multiple nesting during the model runs.

\subsection{Experiment design}

Several 48-h simulations of the case have earlier been realized using different MM5 configurations (Dayan, 2003). All these model runs were initiated at 00:00 UTC, 3 December 2001. A notable sensitivity of the simulation results to the space resolution has been revealed. In accordance with the conclusion a high-resolution model simulation of the event is performed.
A three-nested-domain model simulation of the event was performed with the horizontal spacing of $45 \mathrm{~km}, 15 \mathrm{~km}$ and $5 \mathrm{~km}$, respectively. Two-way interaction approach was adopted in the experiment performed. Results of the earlier performed ensemble simulations of the event (Dayan, 2003) were adopted to determine the positioning of the highresolution domain in the two-way adaptive resolution (Skamarock et al., 1989) simulation experiment. Namely, the $5 \mathrm{~km}$-resolution sub-domain was positioned over the area with high $(>0.8 \mathrm{hPa})$ values of the standard deviation of the predicted $500 \mathrm{hPa}$ geopotential heights (Fig. 4; Fig. 3 in KAD) to better represent the small-scale synoptic developments in the area of the Cyprus Low formation (Coiffer, 2002; Dudhia, 2005; Kalnay, 2002; Krichak, 2005; Ziehmann, 2000). 
Table 1. MM5 configuration.

\begin{tabular}{llll}
\hline Number of points & $73 \times 73$ & $85 \times 67$ & $127 \times 100$ \\
\hline Resolution $(\mathrm{km})$ & 45 & 15 & 5 \\
Number of layers & 37 & 37 & 37 \\
MPHYS & Simple ice & Simple ice & Simple ice \\
ICUPA & Betts-Miller & Grell & Kain-Fritch \\
IBLTYP & Eta Mellor Yamada & MRF & MRF \\
FRAD & Rapid Radiative Transfer Model & 0 & 0 \\
ISOIL & Multi-layer & Multi-layer & Multi-layer
\end{tabular}

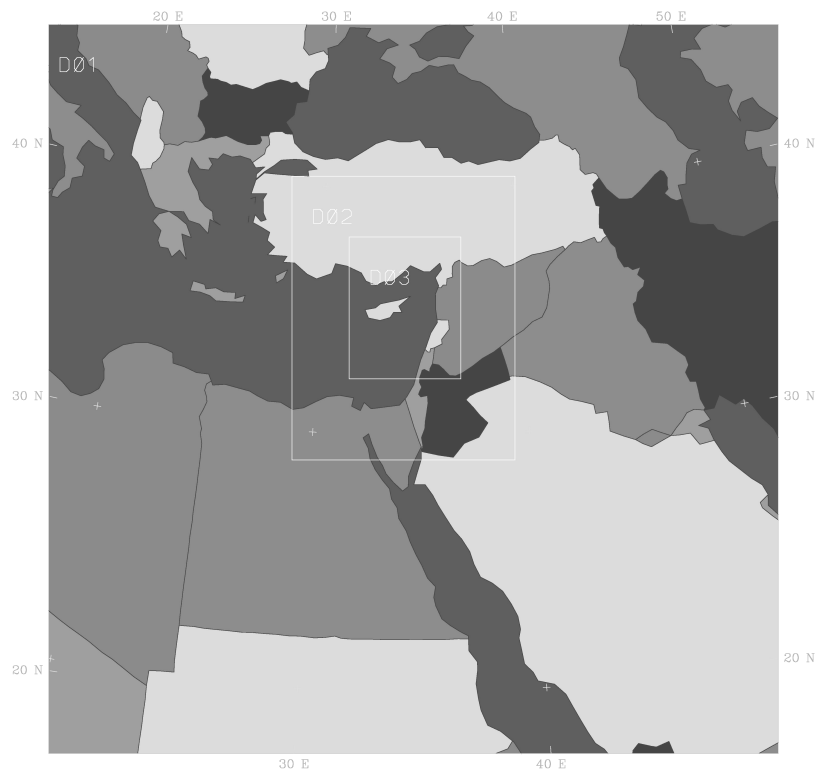

Fig. 4. Domain configuration for MM5 simulation.

The atmosphere in the simulation experiment was represented by 37 layers with the model top at the $70 \mathrm{hPa}$, with the lowest $1500 \mathrm{~m}$ having 13 layers. The adopted model parameters are given in Table 1.

\subsection{Initial data}

Numerical weather forecast data from the Global Forecast System (GFS) at the NCEP are routinely used for highresolution mesoscale weather prediction at Tel Aviv University (TAU) Weather Research Center using a mesoscale model version of the MM5 having 60 and $20 \mathrm{~km}$ space resolution. The GFS spectral model (to the end of 2001) had the T170L42 spectral space resolution $(\sim 75 \mathrm{~km}), 42$ levels in vertical and the model top at $2 \mathrm{hPa}$.

A subset with the GFS forecast data for the period from 00:00 UTC, 3 December 2001 to 00:00 UTC 5 December 2001, with the six-hour time increment was available for the simulations at TAU. The data set covered the area which in- cluded Europe and the Mediterranean region. The surface, soil temperature and humidity data, as well as those at 13 standard isobaric levels $(1000,850,700,600,500,400,300$, $250,200,150,100$ and $70 \mathrm{hPa}$ ) were defined with $1.25 \mathrm{deg}$ lat $\times$ lon resolution. No additional assimilation of the observation data over the region of interest has been performed.

\section{Synoptic evaluation of results}

\subsection{Precipitation}

Six-hourly data on the model-simulated and observed precipitation intensities over the area of Zichron Yaakov are given in Figs. 5a-b, respectively. Thought the model predicts the highest precipitation intensity about $12 \mathrm{~h}$ later than really observed, the simulated precipitation intensities are in reasonable agreement with the observations. It should be noted that the simulated maxima of precipitation rates $(52 \mathrm{~mm}$ sixhours $^{-1}$ ) are $8-10$ times higher than those produced (not presented) with the coarse resolution MM5 version at TAU (Dayan, 2003).

\subsection{Low-troposphere developments}

The SLP, wind and relative humidity $(\mathrm{RH})$ at $700 \mathrm{hPa}$ patterns over the second $(15 \mathrm{~km})$ model domain at 12:00 UTC, 3 December 2001, 00:00 UTC and 12:00 UTC, 4 December 2001 and 00:00 UTC, 5 December 2001, are presented in Figs. 6a-d, respectively. The synoptic process is on its early stage at 12:00 UTC 3 December 2001 (Fig. 6a). Development of a mesoscale trough system may be noted. The trough is already well-formed at 00:00 UTC, 4 December 2001 (Fig. 6b). It intrudes into the Israeli coastal zone along $32.5^{\circ} \mathrm{N}$ at about 12:00 UTC, 4 December 2001 (Fig. 6c). A further propagation of the trough to southeast may be seen in Fig. 6d at 00:00 UTC 5 December 2001.

The CL system with the central pressure of $1002 \mathrm{hPa}$ is situated to the west of Cyprus in Fig. 6a at 12:00 UTC, 3 December 2001. A large zone with high RH-700 values is positioned over the north-eastern (NE) part of the EM region. At the time moment the moist air mass is not included 

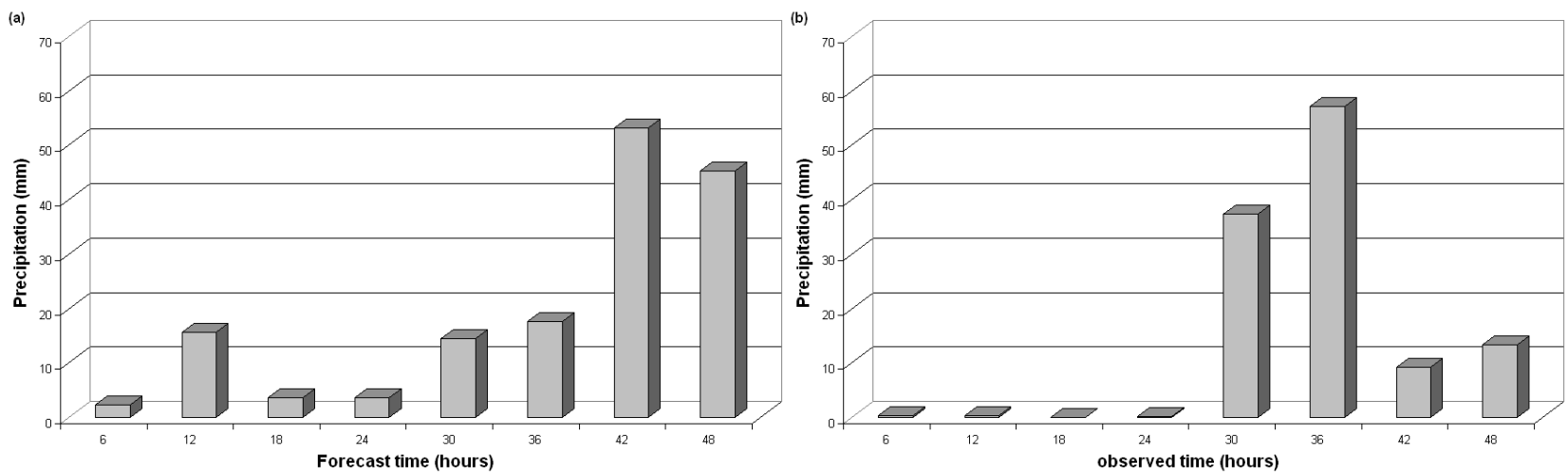

Fig. 5. Precipitation in Israel Zichron Yaakov starting from 00:00 UTC 3 December 2001 to 00:00 UTC $05 \mathrm{December}^{2001}\left(\mathrm{~mm} 6 \mathrm{~h}^{-1}\right)$. (a) model-simulation results, (b) observed.

in the cyclonic system. In Fig. 6b at 00:00 UTC 4 December 2001 the situation is different and the high RH zone over NE Mediterranean area is splitted to two parts with one of them included in the cyclone system. At 12:00 UTC 4 December 2001 the central pressure in the CL to the south of Cyprus equals $1002 \mathrm{hPa}$ (Fig. 6c). The high RH zones are fully separated. One of the moist-air zones is leaving the model domain area in the northeast whereas the second one is found as a narrow band positioned in the vicinity of the cyclone center. In Fig. 6d, at 00:00 UTC, 5 December 2001, the cyclone with the central pressure of $1002 \mathrm{hPa}$ is situated to the south of Cyprus over a narrow zone between Cyprus and the coastal EM. The main area with the high RH values is found over the northern EM. Another part of the high RH zone covers the area of the northern Israel.

\section{Dynamic tropopause analysis}

\subsection{Methodology}

Analyses of the jet stream associated cyclone developments in the extra-tropics are often performed (Agusti-Panareda et al., 2004; Barnes and Colman, 1994; Gallini and Turato, 2005; Haynes and McIntyre, 1990; Hoskins et al., 1985; Morgenstern and Davies, 1999; Neeman and Alpert, 1990; Thorpe, 1985; Tsidulko and Alpert, 2001; Ziv and Alpert, 1994) based on the potential vorticity (PV; Ertel, 1942) approach.

The PV approach allows depicting the upper-tropospheric features of atmospheric processes by determining the dynamic tropopause (DT) level. The tropopause pressure is defined as the atmospheric level with PV value representing tropopause. For the extra-tropics, PV values above $3 \mathrm{PVU}$ (potential vorticity units, $1 \mathrm{PVU}=10^{-6} \mathrm{~K} \mathrm{~m}^{2} \mathrm{~kg}^{-1} \mathrm{~s}^{-1}$ ) are inferred (Barnes and Colman, 1994; Hoskins et al., 1985) to represent stratospheric air. A PV value of $1.5 \mathrm{PVU}$ is often used to determine the tropopause. Application of the
DT concept has become popular (e.g., Morgan and NielsenGammon, 1998; Pyle et al., 2004) due to the fact that the DT perspective makes it possible to present the upper-level features of synoptic processes on a single map. Often the PV streamer systems well correspond well with tropopause-level flow structures which may be determined on DT patterns.

A computer tool has been developed, which allows to infer the DT pressure (PRDT) based on the PV values calculated using the absolute vorticity values determined at the isobaric surfaces (Hoskins et al., 1985; Ma et al., 2003). The DT is defined as the first 1.5 PVU surface determined in a downward search from $200 \mathrm{hPa}$. After the PRDT values are found, the interpolation of the relative humidity (RHDT), potential temperature (THDT) and DT wind components to dynamic tropopause is performed.

\subsection{Dynamic tropopause analysis}

According to the earlier discussed simulation results, an important feature of the 3 December 2001-5 December 2001 synoptic process was associated with seclusion of a very moist air mass into the central part of the CL. The PRDT patterns calculated from results of the MM5 simulation over the $15 \mathrm{~km}$ model domain (from 12:00 UTC, 3 December 2001 to 00:00 UTC, 5 December 2001 with $12 \mathrm{~h}$ time interval) (Figs. 7a-d) allow a deeper understanding of the process.

An isolated PRDT maximum is found over the northern Mediterranean coastal zone of Turkey. The PRDT maximum corresponds to the CL cyclone. Positioning of a narrow highPRDT band (up to $550 \mathrm{hPa}$ ) along the southern coastal zone of the EM (over Egypt) at 12:00 UTC, 3 December 2001 (Fig. 7a) may be noted. The tropopause is nearly vertical over the area.

At 00:00 UTC, 4 December 2001 (Fig. 7c), the zone with the PV streamer displaced to the northeast. The second DT maximum shifted to the east in direction of the island of Cyprus. The developments were associated with the 
(a) MM5: SLP, WND/RH-700 12031201

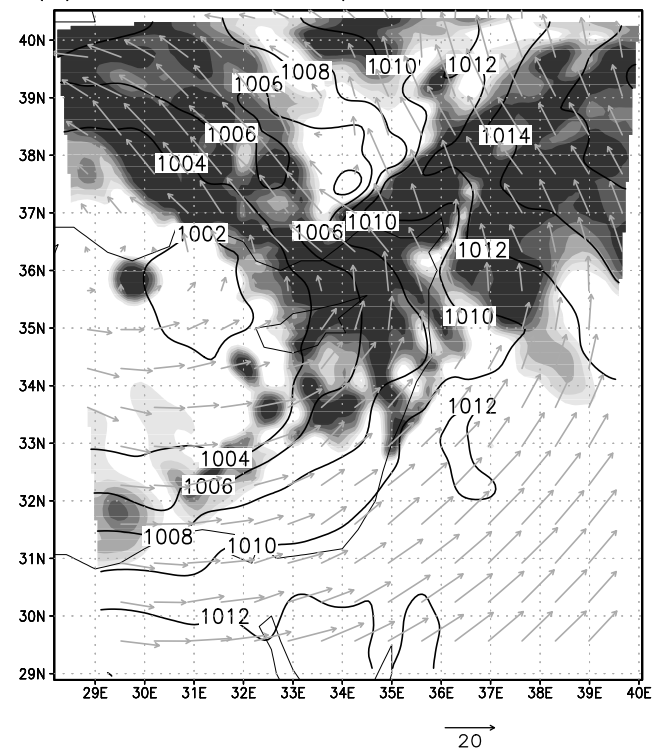

(c) MM5: SLP, WND/RH-700 00041201

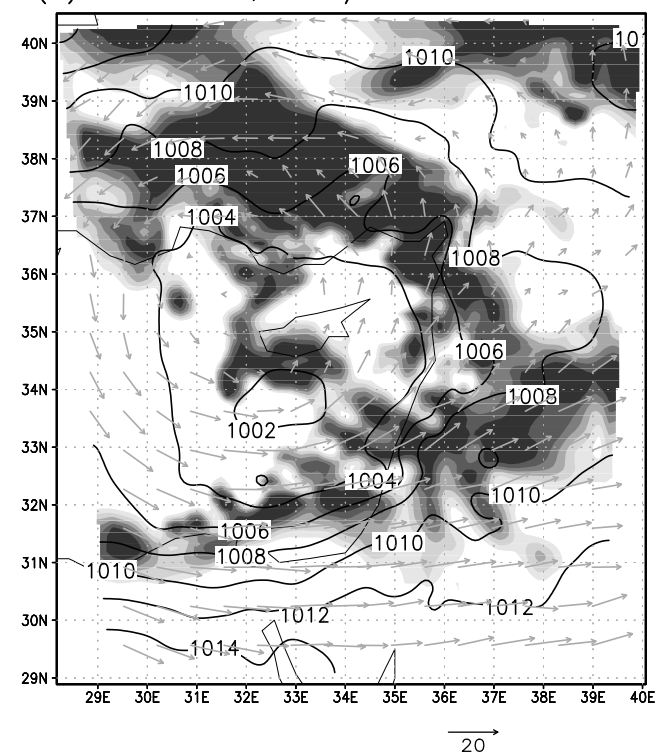

(b) MM5: SLP, WND/RH-700 00041201
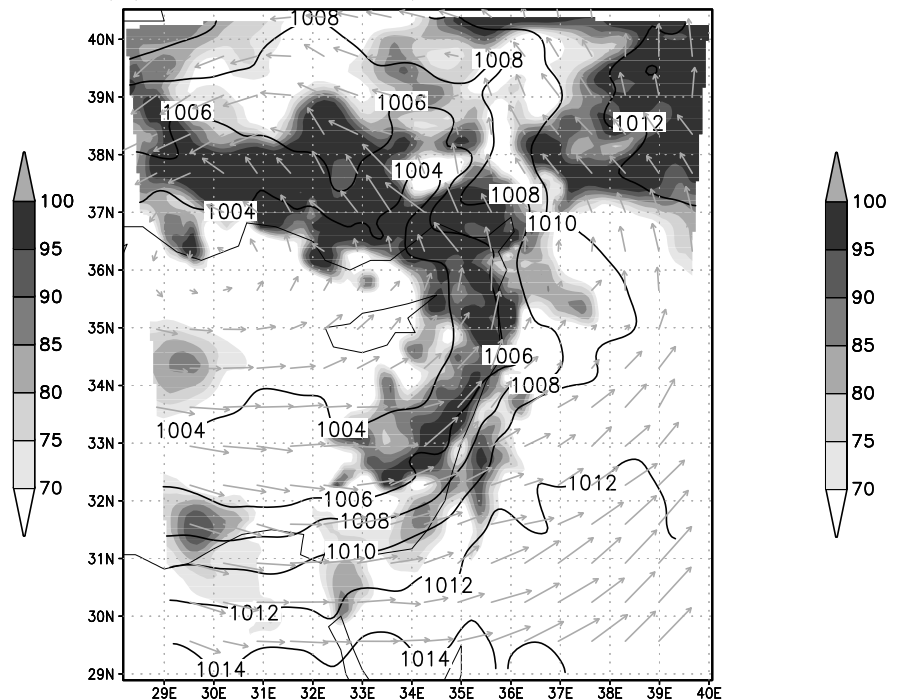

20

(d) MM5: SLP, WND/RH-700 00051201
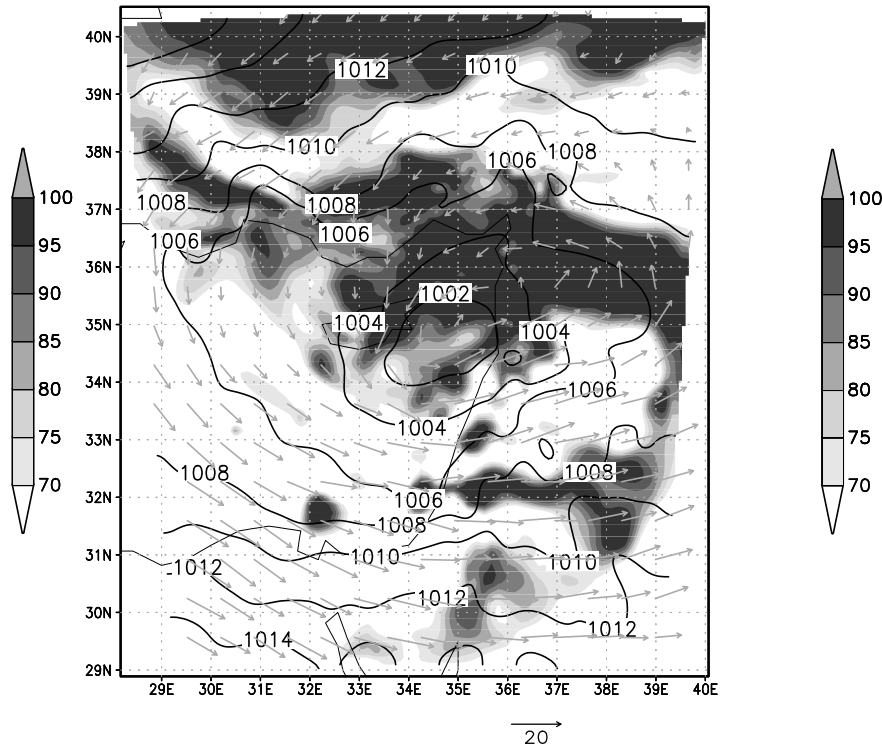

Fig. 6. MM5 simulation: Sea level pressure (solid); relative humidity (shaded) and winds $\left(\mathrm{m} \mathrm{s}^{-1}\right.$ ) at $700 \mathrm{hPa}$ (a) 12:00 UTC 3 December 2001, (b) 00:00 UTC 4 December 2001, (c) 12:00 UTC 4 December 2001 and (d) 00:00 UTC 5 December 2001.

eastward shift of the streamer system. At 00:00 UTC, 5 December 2001 (Fig. 7d), the stratospheric air mass intrusion weakened and a fast eastward (i.e. to Israel) propagation of the CL resulted from the model simulation results (Fig. 6d) takes place.

Further insights can be gained by evaluating the patterns (Figs. 8a-d) of potentional temperature and winds provided in figures of lower space resolution for clarity. At 12:00 UTC, 3 December 2001 (Fig. 8a), a sharp DT gradient along the African coast represents the positioning of the PV streamer. The DT winds in Figs. 8a-d provide additional explanation of the earlier noted (Figs. 1a-d; 6a-d) split of the wet air mass in the northeastern periphery of the EM cyclone. During the period of simulation the upper-troposphere air masses over the southern part of the Mediterranean Sea region and north-Africa are driven by the southwesterly winds. To the south of the area however the process is characterized by almost zonally oriented DT winds associated with the subtropical upper-troposphere jet stream (Figs. 8a-d). 
(a) MM5: PRDT 12031201

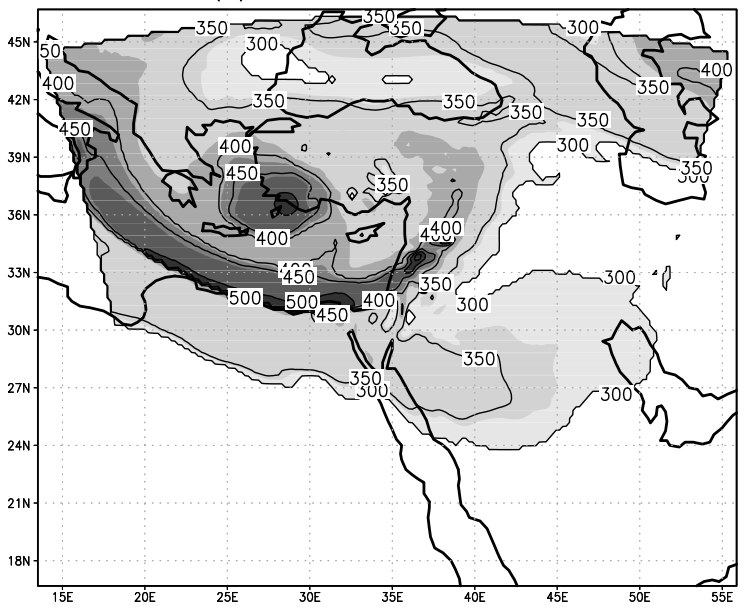

(c) MM5: PRDT 12041201

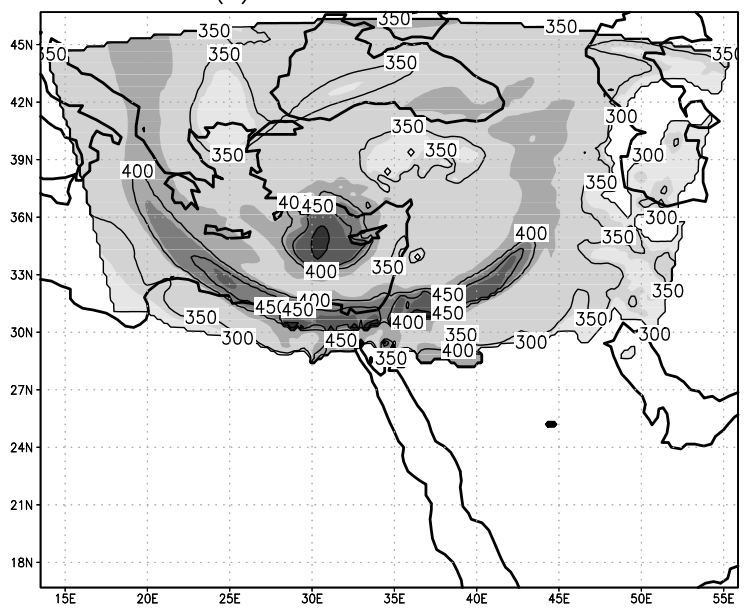

(b) MM5: PRDT 00041201

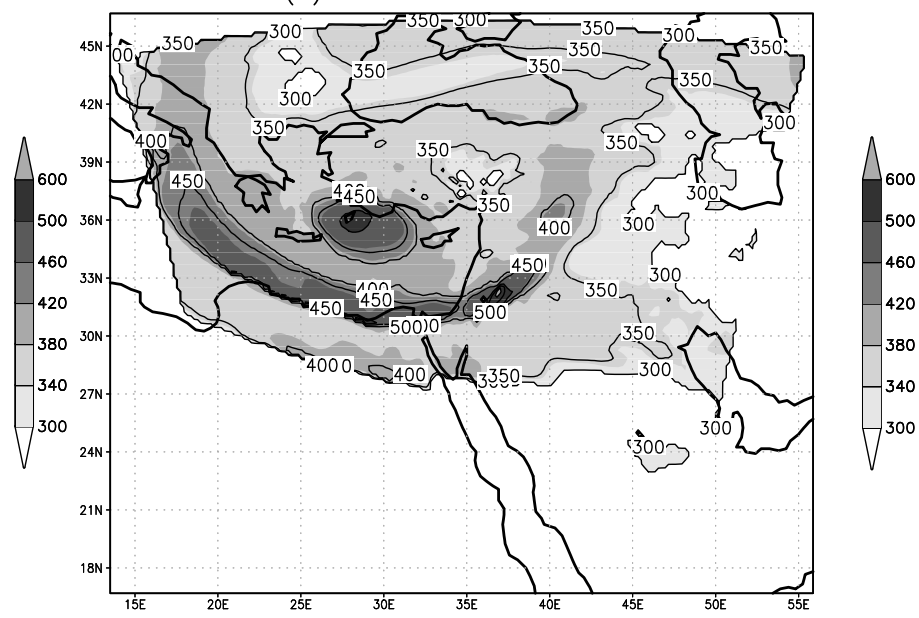

(d) MM5: PRDT 00051201

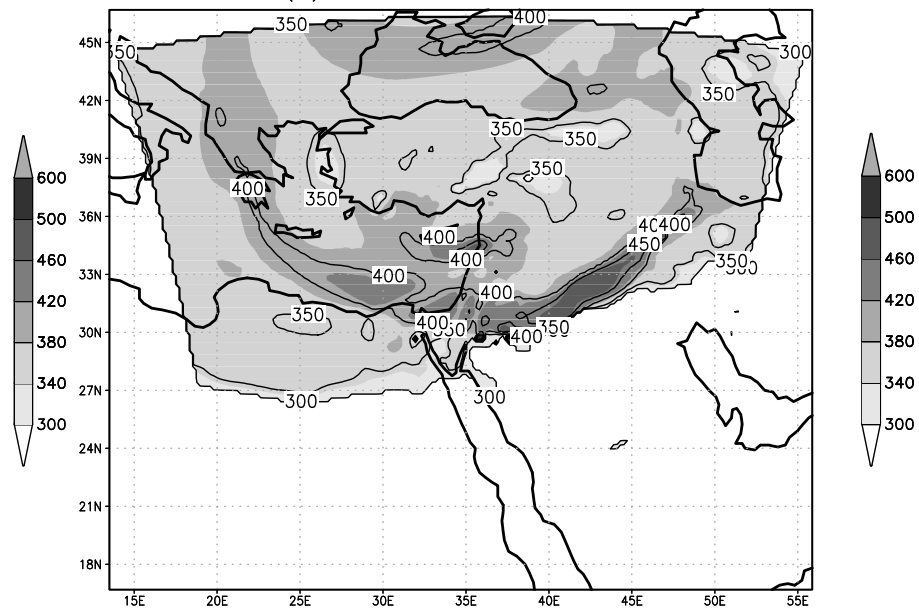

Fig. 7. MM5 simulation: Dynamic tropopause pressure at 12:00 UTC 3 December 2001 3, (b) 00:00 UTC 4 December 2001, (c) 12:00 UTC 4 December 2001 and (d) 00:00 UTC 5 December 2001.

\section{Discussion and conclusion}

Due to the evident differences in the horizontal scales it would not be realistic to expect a full agreement of the model produced prediction of the thunderstorms of 4 December 2001-5 December 2001 in Israel with the observations. One may conclude however that the precipitation intensities as well as the timing of the rainy event in Fig. 5a are reproduced with a satisfactory level of accuracy.

The relative humidity maps at $700 \mathrm{hPa}$ in Figs. $6 \mathrm{a}-\mathrm{d}$ are also in agreement with the Meteosat imageries (Figs. 3a-d). The earlier indicated moisture isolation process is well represented. The dynamic tropopause maps based on the modeling results provide explanation for the physical mechanisms responsible.

According to Figs. 7a-d and 8a-d a nearly vertical tropopause fold took place over the south-eastern part of the Mediterranean region during the period. The DT patterns remained almost unchanged during the $48 \mathrm{~h}$ period (Figs. $7 \mathrm{~b}-$ d), indicating positioning of an intense upper-troposphere PV-streamer system over the central and southern Mediterranean area (Caracena et al., 2001; Fehlmann et al., 2000; Liniger and Davies, 2003; Massacand et al., 1998; Morgan and Nielsen-Gammon, 1998). At 00:00 UTC, 4 December 2001, the PV streamer is found shifted eastward (Fig. 7b). A dry zone between the two parts of the high $\mathrm{RH}$ area over the northeastern Mediterranean is occupied by the air masses of stratospheric origin, which are represented by the dark zone in the WV imageries. The split of the huge air-mass volume with high RH values is clearly associated with the propagation of the PV streamer system.

The PV streamer was positioned unusually far to the south over the Mediterranean region. The system appears in the pictures as a discontinuity in the dynamic tropopause winds, potential temperature and pressure. The earlier discussed moist air cut-off in the developing CL system (Figs. 2a-d) is explainable by the dynamic effects of the PV streamer. 
(a) MM5: THDT WNDT 12031201

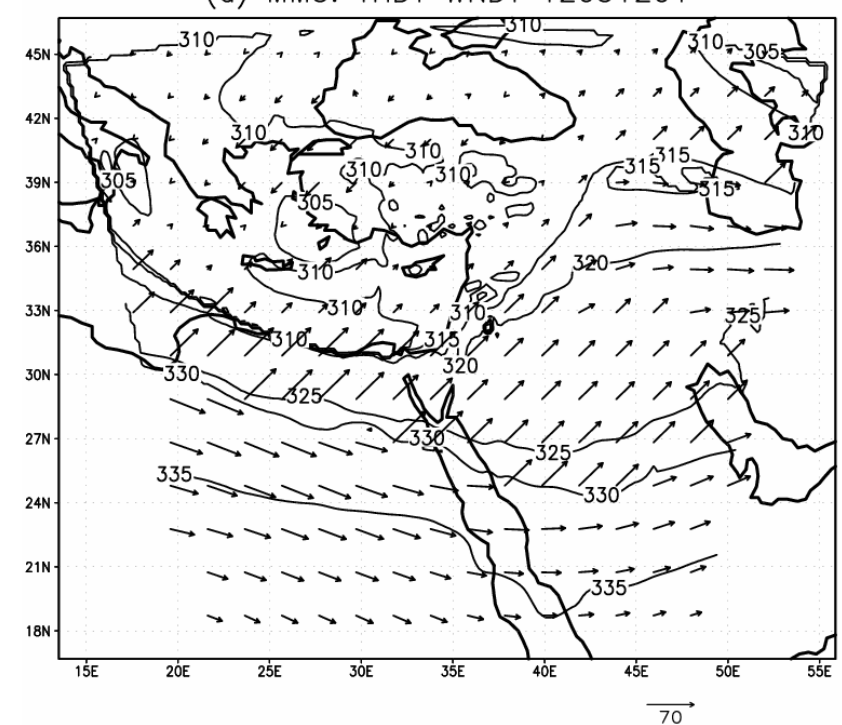

(c) MM5: THDT WNDT 12041201

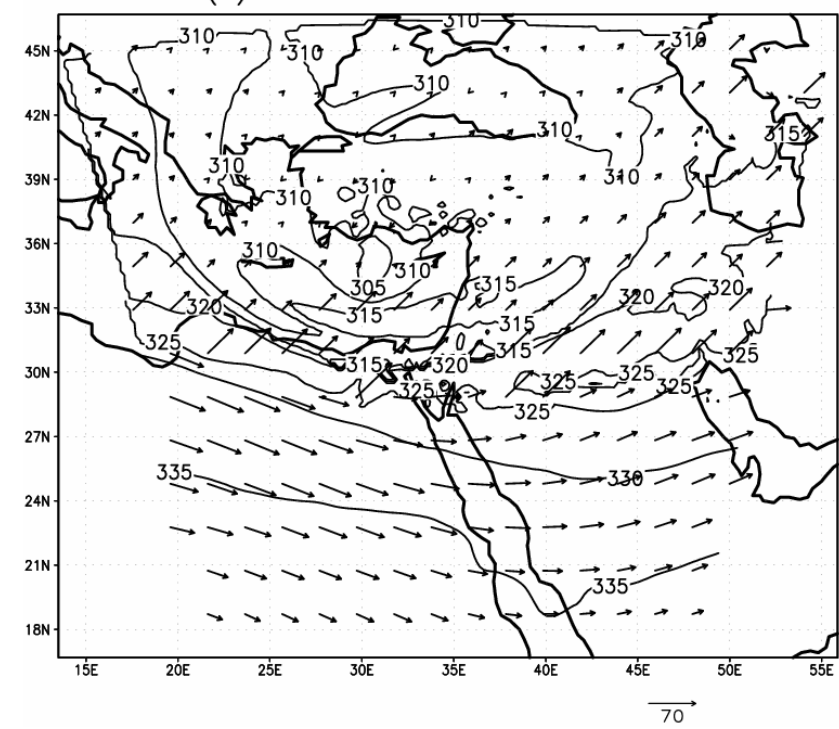

(b) MM5: THDT WNDT 00041201

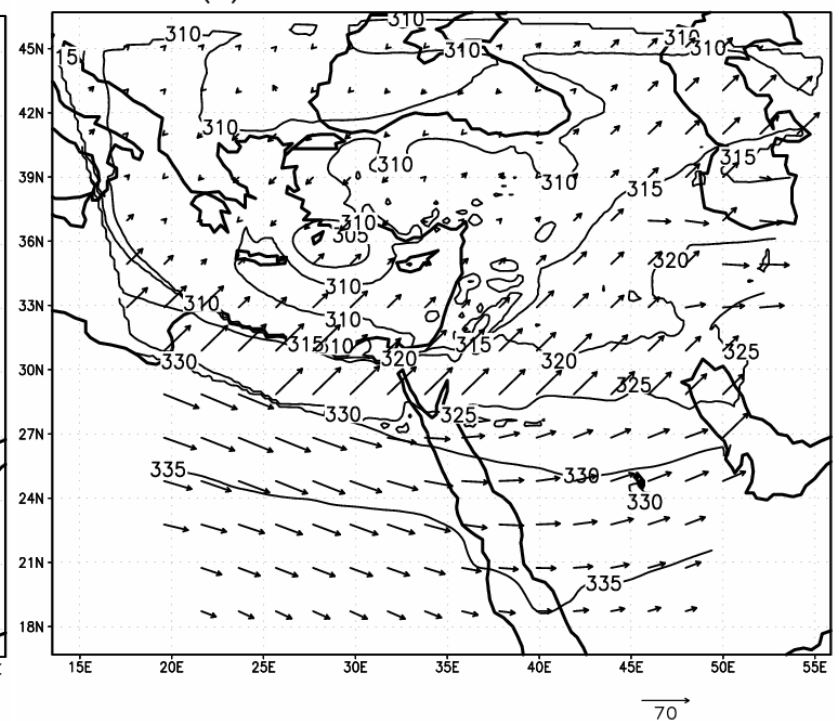

(d) MM5: THDT WNDT 00051201

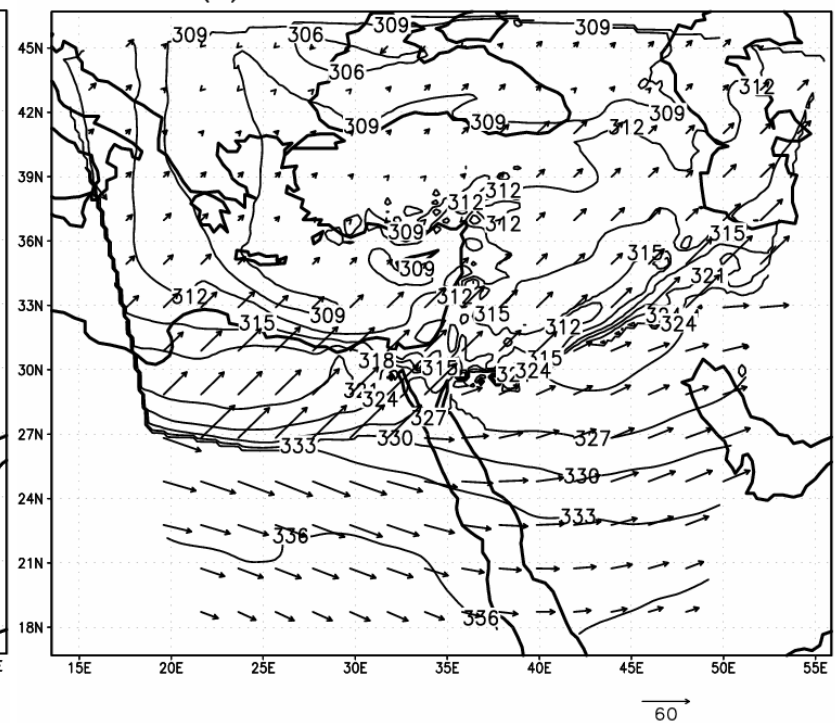

Fig. 8. MM5 simulation: Dynamic tropopause temperature and winds at 12:00 UTC 3 December 2001, (b) 00:00 UTC 4 December 2001, (c) 12:00 UTC 4 December 2001 and (d) 00:00 UTC 5 December 2001.

The unusually intense rainy event in Israel on 4 December 2001-5 December 2001 occurred after the formation of hurricane Olga on 26 November 2001. It has been suggested (KAD) that the Israeli floods results from an intense transport of the moist air masses from the Atlantics to the Mediterranean region. Importance of such processes for the Mediterranean weather has already been indicated (Turato et al., 2004). Results of the current analysis show a more complex scenario of the process however. A major part of the moist air masses that participated in the rainy event in Israel have originated from the Indian Ocean and equatorial Africa (Krichak et al., 2007). Olga's effects have contributed to an increased concentration of moist air over the region. The moist air masses have been transported to the EM region by the air flow in the RST system which developed as a consequence of the STJ intensification over north-Africa. Development of the CL cyclone over the north-eastern Mediterranean as well as concentration of the moist air masses in its central part have resulted from the activity of the intense PV streamer associated with a narrow zone with the tropopause fold extending over the central as well as southeastern Mediterranean areas.

The unprecedented intensity of the 4 December 20015 December 2001 rains in Israel was a consequence of an 
unusually southern penetration of the PV streamer associated with a narrow zone with the tropopause fold. This also explains the failures of the earlier attempts of the model simulations of the event without using appropriate model space resolution of more than 5-10 km (e.g. Buzzi and Foschini, 2000).

The findings have the following major implications. (1) Application of the dynamic tropopause patterns appears to be useful for prediction of small scale intense thunderstorms over the eastern Mediterranean and Israel; (2) Additional research efforts are required for a deeper investigation of the role of the intense north-Atlantic cyclones in the European weather; (3) Synoptic developments characterized by a deep southward displacement of upper-troposphere PV-streamer systems to the southeastern Mediterranean must be considered among the main factors determining the intensity and location of the area of development of the Cyprus Low cyclones.

Acknowledgements. This research is part of the GLOWA - Jordan River Project funded by the German Ministry of Science and Education (BMBF), in collaboration with the Israeli Ministry of Science and Technology (MOST). It was performed in accordance with the program of work under the WMO-MEDEX Project. The authors acknowledge using NCEP reanalysis data provided by the NOAA-CIRES Climate Diagnostics Center, Boulder, Colorado, USA (http://www.cdc.noaa.gov) in this publication. This paper benefited greatly from the constructive comments and suggestions by $\mathrm{O}$. Reale and an anonymous reviewer.

Edited by: A. Mugnai

Reviewed by: O. Reale and another referee

\section{References}

Barnes, S. L. and Colman, B. R.: Diagnosing an Operational Numerical Model Using Q-Vector and Potential Vorticity Concepts, Wea Forecasting, 9, 85-102, 1994.

Buzzi, A. and Foschini, L.: Mesoscale Meteorological Features Associated with heavy precipitation in the Southern Alpine Region, Meteorol. Atmos. Phys., 72(2-4), 0131-0146, 2000.

Caracena, F., Marroquin, A., and Tollerud, E.: A PV-streamer's role in a succession of heavy rain-producing MCSs over the central United States, Phys. Chem. Earth, Part B-Hydrology Oceans and Atmos., 26(9), 643-648, 2001.

Coiffer, J.: Requirements and constrains for meteorological services to manage severe weather, Proc. Tech. Conf. on Data Processing and Forecasting Systems, Cairns, Australia, WMO, available online at http://www.wmo.ch/web/www/DPS/TC-DPFS-2202/ Papers-Posters/Topic3-Coiffer.pdf, 2002.

Dayan, M.: Optimization of the MM5 NWP system for weather research at TAU, M. Sc. Thesis, Tel Aviv University, 85p, 2003.

Cotton, W. R.: Storms, Geophys. Sci. Series, vol. 1, ASTeR Press, Fort Collins, 158 p., 1990.

Dudhia, J., Gill, D., Manning, K., Wang, W., and Bruyere, C.: PSU/NCAR Mesoscale Modeling System Tutorial Class Notes and Users' Guide (MM5 Modeling System Version 3) Updated for MM5 Modeling System Version 3.7, available online at http: //box.mmm.ucar.edu/mm5/documents/, 2005.

El-Fandy, M. G.: Barometric Lows of Cyprus, Quart. J. Roy. Meteorol. Soc., 72, 291-306, 1946.

Ertel, H.: Ein neuer hydrodynamischer Wirbelsatz, Meteorologische Zeitschrift, 59, 22, 1942.

Fehlmann, R., Quadri, C., and Davies, H. C.: An Alpine rainstorm: Sensitivity to the mesoscale upper-level structure, Wea. Forecasting, 15, 4-28, 2000.

Gallini, S. and Turato, B.: An operational approach to the forecast of intense thunderstorms over the Mediterranean, European Geosciences Union, 7th Plinius Conference on Mediterranean Storms, 5-7 October 2005, Rethymnon, Crete, Greece, 2005.

Grell, G., Dudhia, J., and Stauffer, D. R.: A description of the fifth-generation Penn State/NCAR mesoscale model (MM5), NCAR/TN-398+STR, National Center for Atmospheric Research, Boulder, Colorado, 138 p, 1994.

Haynes, P. H. and McIntyre, M. E.: On the conservation and impermeability theorems for potential vorticity, J. Atmos. Sci., 47(16), 2021-2031, 1990.

Hoskins, B. J., McIntyre, M. E., and Robertson, A. W.: On the use and significance of isentropic potential vorticity maps, Quart. J. Roy. Meteorol., Soc., 111, 877-946, 1985.

Kallos, G. and Metaxas, D. A.: Synoptic processes for the formation of Cyprus lows, Rivista Meteorologia Aeronautica, XL(23), 121-138, 1980.

Kalnay, E., Kanamitsu, M., Kistler, R., et al.: The NCEP/NCAR 40Year Reanalysis Project, Bull. Am. Meteorol. Soc., 77, 437-471, 1996.

Kalnay, E.: Atmospheric Modeling, Data Assimilation and Predictability, Cambridge University Press, 512 p., 2002.

Keyser, D. and Shapiro, M. A.: A review of the structure and dynamics of upper-level frontal zones, Mon. Wea. Rev., 452-499, 1986.

Kistler, R., Collins, W., Saha, S., et al.: The NCEP-NCAR 50-year Reanalysis: Monthly Means CD-ROM and Documentation, Bull. Amer. Meteorol. Soc., 82, 247-268, 2001.

Krichak, S. O., Alpert, P., and Krishnamurti, T. N.: Interaction of topography and tropospheric flow - A possible generator for the Red Sea Trough?, Meteorol. Atmos. Phys., 63(3-4) 149-158, 1997a.

Krichak, S. O., Alpert, P., and Krishnamurti, T. N.: Red Sea Trough/Cyclone development, Numerical Investigation, Meteorol. Atmos. Phys., 63(3-4) 159-170, 1997b.

Krichak, S. O. and Alpert, P.: Role of large-scale moist dynamics in the November 1-5, 1994 hazardous Mediterranean weather, J. Geophys. Res.-Atmos., 103(D16), 19453-19468, 1998.

Krichak, S. O., Alpert, P., and Dayan, M.: Role of atmospheric processes associated with hurricane Olga in December 2001 flash floods in Israel, J. Hydrometeorol., 5(6), 1259-1270, 2004.

Krichak, S. O.: An adaptive resolution study of December 3-5 2001 Mediterranean cyclone with torrential rains in Israel, Conference on "Current efforts towards advancing the skill of regional weather prediction. Challenges and outlook", 20-22 April, International Center for Theoretical Physics, Trieste, Italy, 2005.

Krichak, S. O., Alpert, P., and Dayan, M.: An evaluation of the role of Hurricane Olga (2001) in an extreme rainy event in Israel using dynamic tropopause maps, Meteorol. Atmos. Phys., in press, 2007. 
Krishnamurti, T. N.: The subtropical jet stream of winter, J. Meteorol., 18, 172-191, 1961.

Liniger, M. A. and Davies, H. C.: Substructure of a MAP streamer, Quart. J. Roy. Meteorol. Soc., 129, 633-651, 2003.

Maddox, R. A.: Mesoscale convective complexes, Bull. Amer. Meteorol. Soc., 61, 1337-1367, 1980.

Massacand, A. C., Wernly, H., and Davies, H. C.: Heavy precipitation on the Alpine south-side: An upper-level precursor, Geophys. Res. Lett., 25, 1435-1438, 1998.

Mesinger, F. and Arakawa, A.: Numerical methods used in atmospheric models, v. 1 WMO GARP Publication Series No. 17, 64 p, 1976.

Morgan, C. M. and Nielsen-Gammon, J. W.: Using tropopause maps to diagnose midlatitude weather systems, Mon. Wea. Rev., 126, 2555-2579, 1998.

Morgenstern, O. and Davies, H. C.: Desruption of an upper-level PV-streamer by orographic and cloud-diabatic effects, Contr. Atmos. Phys., 12(2), 173-186, 1999.

Neeman, B. N. and Alpert, P.: Visualizing atmospheric fields on a personal computer: Application to potential vorticity analysis, Bull. Amer. Meteorol. Soc., 71, 154-160, 1990.

Pyle, M. E., Keyser, D., and Bosart, L. F.: A diagnostic study of jet streaks: Kinematic signatures and relationship to coherent tropopause disturbances, Mon. Wea. Rev., 132(1), 297-319, 2004.

Reed, R. J., Stoelinga, M. T., and Kuo, Y.-H.: A model-based study of the origin and evolution of the anomalously high potential vorticity in the inner region of a rapidly deepening marine cyclone, Mon. Wea. Rev., 120, 893-913, 1992.
Skamarock, W., Oliger, J., and Street, R.: Adaptive grid refinement for numerical weather prediction, J. Comp. Phys., 80, 27-60, 1989.

Thorpe, A. J.: Diagnosis of a balanced vortex structure using potential vorticity, J. Atmos. Sci., 42, 397-406, 1985.

Tsidulko, M. and Alpert, P.: Synergism of upper-level potential vorticity and mountains in Genoa lee cyclogenesis - A numerical study, Meteorol. Atmos. Phys., 78(3-4), 261-285, 2001.

Turato, B., Reale, O., and Siccardi, F.: Large scale water vapor sources relative to the October 2000 Piedmont flood, J. Hydrometeorol., 5, 693-712, 2004.

Uccellini, L. W.: On the role of upper tropospheric jet streaks and leeside cyclogenesis in the development of low level jets in the Great Plains, Mon. Wea. Rev., 108, 1689-1696, 1980.

Uccellini, L. W. and Kocin, P. J.: The interaction of jet streak circulations during heavy snow events along the east coast of the United States, Wea. Forecasting, 2, 289-308, 1987.

Whitaker, J. S., Uccellini, L. W., and Brill, K. F.: A model-based diagnostic study of the rapid development phase of the Presidents' Day cyclone, Mon. Wea. Rev., 116, 2337-2365, 1988.

Ziehmann, C.: Comparison of a single model EPS with a multimodel ensemble consisting of a few operational models, Tellus, 52A, 280-299, 2000.

Ziv, B. and Alpert, P.: Isobaric to isentropic interpolation errors and implication to PV analysis, J. Appl. Meteorol., 33, 694-703, 1994.

Ziv, B., Dayan, U., and Sharon, D.: A mid-winter, tropical extreme flood-producing storm in southern Israel: Synoptic scale analysis, Meteorol. Atmos. Phys., 88(1-2) 53-63, doi:10.1007/s00703-003-0054-7, 2004. 